\title{
Legal Education, Social Mobility and Employability: Possible Selves, Curriculum Intervention and the role of Legal Work Experience
}

\begin{abstract}
ANDREW FRANCIS*
This paper interrogates a number of assumptions underpinning the recent focus on employability and social mobility within legal education and the legal profession - in particular the capacity of legal work experience to support these policy objectives.

It draws on research evidence to argue that a narrow focus upon the individual acquisition of skills and attributes fails to capture the fuller complexity of legal employability as a negotiated, situated process. It shows how the structuring properties of the field reduce the capacity of employability initiatives to disrupt the patterns of social and cultural reproduction that frame access to the legal profession. In this context, the potential of curriculum intervention to enhance employability is inhibited by the structural constraints upon the possible selves that law students are able to imagine. It suggests that students' opportunities are not only shaped by their past, but are also constrained by their possible futures.
\end{abstract}

\section{INTRODUCTION}

Legal education and the wider profession have been challenged to meet the social mobility aspirations of students and government. ${ }^{1}$ Graduates now assume a significant element of the burden of funding higher education and the business-university nexus occupies a central place within mainstream political discourse. ${ }^{2}$ Within this context, student employability has been stressed to ensure that universities produce graduates with the skills and attributes that industry requires and individual graduates are positioned as strongly as possible within a competitive labour market.

Legal employability and social mobility initiatives have each been held out as critical in enhancing the ability of individual students to secure access to the profession, irrespective of socio-economic background and based solely on their skills and attributes, and there has been an increasingly high profile emphasis on these activities within the sector. ${ }^{3}$ Moreover, commentators have indicated that the employability agenda can, in fact, support both objectives. $^{4}$

\footnotetext{
* School of Law, Keele University, Staffordshire, ST5 5BG, UK. a.m.francis@keele.ac.uk. My thanks to Hilary Sommerlad, Julian Webb and the anonymous reviewers for their insightful comments on a previous draft.

${ }^{1}$ Legal Education and Training Review (LETR) Setting Standards: The future of legal services education and training regulation in England and Wales (2013), Para $7.43<$ http://letr.org.uk/the-report/index.html> and A. Milburn, Fair Access to Professional Careers: A progress report by the Independent Reviewer on Social Mobility and Child Poverty (2012) <https://www.gov.uk/government/publications/fair-access-to-professionalcareers-a-progress-report>.

$\frac{2}{2}$ T. Wilson A Review of Business - University Collaboration (2012)

3 A search of "UK Law School employability" produces results from effectively every legal education provider.

${ }^{4}$ G. Watts, Career Development Learning and Employability (2006), 5.
} 
This version was accepted for publication on the $28^{\text {th }}$ January 2015 . The definitive version is available at www.blackwellsynergy.com.

Legal work experience is an important lens through which to interrogate 'employability'. It has been framed as a crucial way in which 'employability' can be enhanced. ${ }^{5}$ Moreover, it has been identified by LETR and the Social Mobility Foundation as a key site of reform to address social mobility concerns in the profession. ${ }^{6}$ This paper will highlight the complex ways in which prior social and educational background shape future opportunities and will argue that, in terms of employability and social mobility returns, legal work experience should not be seen as an uncontested good.

Legal employability has never been more significant for students or their Law Schools. Although there is literature which reflects on what the relationship between legal education and the profession ought to be, ${ }^{7}$ the enhanced significance of employability for legal education has received little critical attention to date. ${ }^{8}$ This paper draws on empirical research, presented in full for the first time, to question a number of assumptions underpinning employability, social mobility and curriculum intervention within Law Schools. It argues that legal employability has to be understood, not only in terms of what employers want and the skills and attributes individuals can develop but, through applying the psychological concept of 'Possible Selves', what students imagine they can become. ${ }^{9}$ These insights challenge 'employability' strategies, such as 'work experience'. Moreover, if curriculum intervention is to assist students in realising their ambitions (and perhaps also support social mobility), this paper argues that such strategies need to be informed by a more complex reading of legal employability, as a negotiated and situated process. This is even more significant as a fragmenting legal labour market, and the growing diversity of routes to qualification within it, challenges the framing of employability for law graduates as simply in relation to the solicitors' or barristers' professions. Although my focus is on 'legal employability' as framed by the traditional legal profession, I am not valorising that sector in terms of career destination. Rather, I seek to use it as a case-study through which to highlight the importance of social and educational background in shaping life chances, and to challenge the notion of the legal labour market as a neutral sphere within which individuals succeed by virtue of their own merit. ${ }^{10}$

\section{BACKGROUND: THE CHANGING CONTEXT FOR LEGAL EDUCATION AND HIGHER EDUCATION SOCIAL MOBILITY, EMPLOYABILITY AND ACCESS TO THE LEGAL PROFESSION}

\footnotetext{
${ }^{5}$ R. Dearing, The Dearing Report, Higher education in the learning society: Report for the National Committee of Inquiry into Higher Education (1997), 136. See also op.cit. n2, rec. 4 and G. Mason et al (2006) Employability Skills Initiatives in Higher Education: What Effects do they have on Graduate Labour Market Outcomes? 9.

${ }^{6}$ LETR op.cit. n1, para 7.51 ; <http://www.socialmobility.org.uk/programmes/aspiring-professionalsprogramme/>

${ }^{7}$ A. Bradney, Conversations, Choices and Chances: The Liberal Law School in the Twenty-first Century (2003); M. Thornton, Privatising the Public University: The Case of Law (2012).

${ }^{8}$ One 'employability' initiative is described in R. Russell, 'Enhancing Employability for LLB Law graduates initiatives with ILEX and Clinic at London South Bank University’ (2011) 45 The Law Teacher 348. Sommerlad provides a sophisticated analysis of 'graduate identity' in the legal profession, but it is beyond the scope of that piece to deal in any depth with the educational implications (H. Sommerlad, 'The commercialisation of law and the enterprising legal practitioner: continuity and change' (2011) 18 International J. of the Legal Profession 73.

${ }^{9}$ H. Markus and P. Nurius, 'Possible Selves' (1986) 41 American Psychologist 954

${ }^{10}$ P. Bourdieu, 'The Force of Law: Toward a Sociology of the Juridical Field' (1987) 38 Hastings Law Journal 805 at 820 .
} 
This version was accepted for publication on the $28^{\text {th }}$ January 2015. The definitive version is available at www.blackwellsynergy.com.

While any number of graduates may, in theory, be employable, a much smaller number are likely to be employed. This is, of course, exacerbated during a period in which youth unemployment is rising, ${ }^{11}$ and the numbers of entry-level positions in the profession are restricted. ${ }^{12}$ Moreover, reductions in scope and eligibility of legal aid raise not just access to justice concerns but also call into question the sustainability of the sector and the criminal bar. ${ }^{13}$ These issues create a difficult context for the legal profession's capacity to deliver social mobility in terms of access to and progress within its ranks.

It has been argued that social mobility problems within professions are linked to the lingering effects of occupational closure. ${ }^{14}$ Professions occupied a prominent role in society, in part, because they were able to control the numbers and types of entrants to the profession. ${ }^{15}$ However, there have been dramatic improvements in terms of socio-demographic diversity within the legal profession since the $1970 \mathrm{~s},{ }^{16}$ and the profession's collective control over entry has weakened. ${ }^{17}$ Over the past twenty years, the legal profession has become more diverse than ever before, with strong progress made, in particular, by women. ${ }^{18}$ Yet, despite these welcome developments, concerns continue to be raised. ${ }^{19}$ Social class and ethnicity remain powerful factors and Sommerlad has argued that, notwithstanding the increasingly bureaucratic processes of recruitment, personalist ties and instinctive assumptions about merit continue to reinforce socio-economic privilege. ${ }^{20}$

Employability has been an influential agenda within higher education since the late 1990s. ${ }^{21}$ Pegg et al. assert that it will continue to be a crucial part of higher education 'in an era of increased costs, higher fees and loans and increased competition for initial and continuing employment locally and nationally'. ${ }^{22}$ A central feature of the discourse asserts that students undertake undergraduate degrees to 'become employable', ${ }^{23}$ an assumption which has, in fact, come to define the entire funding mechanism for higher education in England and Wales. ${ }^{24}$ Consequently, universities work hard to demonstrate and market ${ }^{25}$ the range of ways in which they enhance their students' employability. ${ }^{26}$

\footnotetext{
${ }^{11}$ K. Sellgren, 'Young people 'feel they have nothing to live for' (2014) <http://www.bbc.co.uk/news/education25559089>

${ }^{12}$ N. Fletcher, Annual Trends in the Solicitors' Profession 201242.

${ }^{13}$ C. Baksi, 'Civil Legal Aid: Access Denied?' (2014) < http://www.lawgazette.co.uk/law/civil-legal-aid-accessdenied/5040722.article>.

${ }^{14}$ A. Witz, Professions and Patriarchy (1992).

${ }^{15}$ M. Larson, The Rise of Professionalism: A sociological analysis (1977); R. Abel The Legal Profession in England and Wales (1988) 169-76.

${ }^{16} \mathrm{~J}$. Braithwaite, 'The strategic use of demand side diversity pressure on the solicitors' profession' (2010) $37 \mathrm{~J}$. of Law and Society 442.

${ }^{17}$ R. Abel, English Lawyers Between Market and State: The Politics of Professionalism (2003).

${ }^{18}$ Fletcher, op.cit., n12, p.43

${ }^{19}$ H. Sommerlad et al., Diversity in the Legal Profession in England and Wales: A Qualitative Study of Barriers and Individual Choices (2010)

<http://www.legalservicesboard.org.uk/what_we_do/Research/Publications/pdf/lsb_diversity_in_the_legal_prof ession_final.pdf $>$ and LETR op.cit. $n 1$.

${ }^{20}$ Sommerlad, op.cit., n8, p.96.

${ }^{21}$ M. Clarke, 'Where to from here? Evaluating employability during career transition' (2007) 13 J. of Management and Organisation 196.

${ }^{22}$ A. Pegg et al., Pedagogy for employability (2012) 6.

${ }^{23}$ A. Bradney 'English university law schools, the age of austerity and human flourishing' (2011) 18 International J. of the Legal Profession 59, at 60.

${ }^{24} \mathrm{~J}$. Browne An Independent Review of Higher Education Funding and Student Finance (2010) <http://www.independent.gov.uk/browne-report>.
} 
This version was accepted for publication on the $28^{\text {th }}$ January 2015. The definitive version is available at www.blackwellsynergy.com.

The focus on 'employability' has been overwhelmingly skills based - this is what is needed to enhance employability because these are the skills that employers say they require. The Higher Education Academy (HEA) provides the following definition:

a set of achievements, skills, understandings and personal attributes that makes graduates more likely to gain employment and be successful in their chosen occupations which benefit themselves, the workforce, the community and economy. ${ }^{27}$ Thus, Pegg et al. note that the focus from government and industry has been to ensure that graduates are "Future Fit" ${ }^{28}$ and the CBI/NUS further highlight the specific skills and aptitudes that employers look for. ${ }^{29}$ The Leitch Report stresses that 'Skills is the most important lever within our control to create wealth and to reduce social deprivation' and that "Economically viable skills" is our mantra'. ${ }^{30}$ It also advocates the importance of strengthening the employer voice in skills development ${ }^{31}$ - a connection which, in the context of universities, is the entire focus of the Wilson Review.

There are extensive guides to universities' integration of employability into their programmes, whether that be through skills modules, embedded approaches throughout the curriculum, personal development planning (PDP) and career management planning. ${ }^{32}$ Much of this literature asserts the mainstream policy argument as justification for the initiatives. ${ }^{33}$ Thus, Prior re-iterates that, 'graduates need to be prepared for what employers want and to be able to make a contribution early on in their careers.... ${ }^{34}$ From this perspective, employability is individualised and is seen in absolute terms. The economy needs graduates with particular skills and attributes and it is the responsibility of an individual to enhance their own employment prospects. ${ }^{35}$

In parallel to these developments in higher education generally, there has been an increasing adoption of the language of employability across legal education - not least in marketing programmes to prospective undergraduates. The nexus between the profession and legal

\footnotetext{
${ }^{25}$ N. Foskett 'Marketisation and Education Marketing: The Evolution of a Discipline and a Research Field' in The Management and Leadership of Educational Marketing: Research, Practice and Applications (Advances in Educational Administration, Volume 15) ed. I. Oplatka and J. Hemsley-Brown (2012) 39-46.

${ }^{26}$ M. Thornton and L. Shannon, "'Selling the Dream": Law School Branding and the Illusion of Choice', (2013), 23 Legal Education Review 249.

${ }^{27} \mathrm{http} / / / \mathrm{www}$. heacademy.ac.uk/employability.

${ }^{28}$ Pegg et. al., op.cit. n22, p.6.

${ }^{29}$ Working towards your future: Making the most of your time in higher education (2011)

<http://www.cbi.org.uk/media/1121431/cbi_nus_employability_report_march_2011.pdf>

${ }^{30}$ Prosperity for all in the Global Economy-World Class Skills: Final Report (2006) at 7.

${ }^{31}$ Id., p.9. See also K. Sellgren, 'Warning of worsening in UK skills shortage' (2014)

$<$ http://www.bbc.co.uk/news/education-25945413> reporting that 'employers struggled to find employees with the "core generic skills" of communication, literacy and numeracy.'

${ }^{32}$ M. Yorke, R. Pilkington and K. Mason O-Connor Employability: a Rationale and Examples of Practice (2005); M. Yorke and P. Knight, Embedding Employability into the Curriculum (2006); P. Knight and M. Yorke Employability: judging and communicating achievements (2006); M. Shaw, R. Healey and R. Pilkington, Pioneering Employability in the HE Curriculum (2003); HEA Personal Development Planning and Employability (2006).

${ }^{33}$ This could also operate as a strategy to secure institutional buy-in (Pegg et al. op.cit. n22, p.13).

${ }^{34}$ C. Prior (2005) 'Career Management Skills and work placements in Cultural Studies' in Yorke et al. op.cit. n32, p.30; Watts op.cit. n4, p.5.

${ }^{35}$ Department for Education and Employment (DfEE) A special issue of higher education digest presenting DfEE higher education development projects (2000) ; J. Hillage and A. Pollard, Employability: developing a framework for policy analysis, DfEE Research Briefing Paper No.85 (1998); Browne op.cit. n34.
} 
This version was accepted for publication on the $28^{\text {th }}$ January 2015 . The definitive version is available at www.blackwellsynergy.com.

educators is increasingly a statement of reality - at least in the context of student employability. Students understandably want to secure employment, ${ }^{36}$ and employers (law firms and chambers) want to employ individuals with the skills and attributes that they require. ${ }^{37}$ The employability agenda, premised as it is with equipping graduates with the requisite skills, achievements and understandings for the labour market, in principle, addresses these concerns. Thus, as legal employability for students becomes more prominent than ever before, so too does the relationship between Law Schools and the profession. ${ }^{38}$

The grumblings of the profession about the capacity of graduates to deliver on 'day one, ${ }^{39}$ and indeed a wider questioning of the fitness for purpose of the entire legal education and training system, ${ }^{40}$ led, in part, to the establishment of LETR. Although the regulators have shown limited interest in dictating the detail of employability, the broader drivers of "what recruiters want' more informally shapes concerns within legal education. Even as formal regulatory ties are loosened, ${ }^{41}$ market drivers strengthen the orientation to the profession. Given these developments, and enduring concern about social mobility and access to the legal profession, it is more important than ever to think critically about employability within the context of legal education.

\section{SITUATING LEGAL EMPLOYABILITY}

Employability should be understood in the context of an increasingly competitive and complex labour market, ${ }^{42}$ which requires graduates to differentiate themselves. ${ }^{43}$ Brown and Hesketh argue that the 'official' story of 'employability and graduate recruitment messages which focus on skills, knowledge and attributes pay insufficient attention to the absolute and relative meanings of employability - the "duality of employability. ${ }^{44}$ They offer a more ambiguous and uncertain definition - the 'relative chances of getting and maintaining different kinds of employment' and remind us that 'it is possible to be employable and not in employment'. ${ }^{45}$ Understanding these relative chances requires us to interrogate the ways in which individuals are differentially positioned in the graduate labour market and what aspects of their personal capital are prioritised. Similarly, Tomlinson argues that 'employability must

\footnotetext{
${ }^{36}$ Hardee identifies students' desire for more problem solving and practice skills (M. Hardee Career Expectations of Students on Qualifying Law Degrees in England and Wales (2012). See also LETR op.cit. n1, para 2. 103, reporting student requests for more skills and employability based activities.

${ }^{37}$ The City of London Law Society states that its members 'feel that the profession... through its regulatory arm might need to have greater control over both the standards and content of the QLD...' (City of London Law Society Response to the LETR Discussion Paper 02/12,) (2012) 12)

${ }^{38}$ Although it is also one that in formal regulatory terms at least, remains mired in uncertainty 〈http://www.sra.org.uk/sra/policy/training-for-tomorrow.page>.

39 Joint Academic Stage Board of the Law Society and Bar Council (JASB) The Academic Stage of Training for Entry to the Legal Profession: Standards, Content and related issues (2002) 12.

${ }^{40}$ D. Edmonds 'Training the lawyers of the future - A regulator's view' Upjohn Lecture (2010)

${ }^{41}$ SRA Training for Tomorrow Consultation Response (2014)

${ }^{42}$ R. Abel, 'What does and should influence the number of lawyers?' (2012) 19 International J. of the Legal Profession 131.

${ }^{43}$ P. Brown and A. Hesketh The mismanagement of talent: Employability and jobs in the knowledge-based economy (2004) 30; M. Tomlinson 'Investing in the self: structure, agency and identity in graduates' employability’ (2010) 4 Education, Knowledge \& Economy, 73.

${ }_{44}$ Brown and Hesketh, op.cit., n43, p.24.

${ }^{45}$ Id., p. 25
} 
This version was accepted for publication on the $28^{\text {th }}$ January 2015. The definitive version is available at www.blackwellsynergy.com.

be seen as a socially active process by the way graduates position themselves and are positioned. ${ }^{, 46}$

Drawing on Bourdieu's concepts of habitus and of cultural capital enables us to understand how that prior positioning, in terms of background, education, family and so on, shapes an individual's position within the social field. ${ }^{47}$ The habitus is the durable ways of 'speaking, walking and thereby of feeling and thinking, ${ }^{48}$ required to demonstrate that an actor is 'objectively compatible' with the properties of a social field. ${ }^{49}$ Those without the appropriate habitus have their possibilities for action severely constrained. ${ }^{50}$

There are other contemporaneous signals from the social and economic world that successful graduates are likely to have internalised. ${ }^{51}$ Thus, Brown and Hesketh argue that a key dimension of this is agency in deploying the economic value of self, ${ }^{52}$ which involves the development of a narrative of employability. Crucially, this is a narrative that needs to be 'worked at'; it is a reflexive project of the self. ${ }^{53}$ An aspect of this reflexive graduate identity is seen in the entrepreneurial self that Sommerlad argues is a critical aspect of the normative professional identity demanded by large corporate law firms in their graduate recruitment. ${ }^{54}$ Many graduates face challenges in demonstrating the appropriate cultural capital, ${ }^{55}$ which denotes the required entrepreneurialism; thus their habitus shapes their life chances. ${ }^{56}$ Beagan's assertion that the 'repertoire of the possible' is not equally possible ${ }^{57}$ is powerfully borne out in the interrogation of employability through the lens of legal work experience that is set out in the rest of this paper.

\section{METHODOLOGY}

In order to address these core questions about legal employability, this paper draws on the findings of the 'Legal Work Experience' study, conducted with Hilary Sommerlad and supported by UKCLE. ${ }^{58}$ 'Legal work experience' refers principally to two key types; informally arranged work experience from anything from one day to a number of weeks (from as early as Year 10 onwards) and Formal Vacation Schemes, typically aimed at undergraduate law students to support firms' recruitment strategies.

\footnotetext{
${ }^{46}$ Tomlinson, op.cit., n43, p.74.

${ }^{47}$ P. Bourdieu The Logic of Practice (1990) 59.

${ }^{48}$ Id., p. 70

${ }^{49}$ Id., p.54

${ }^{50}$ Id., p.68

${ }^{51}$ Tomlinson op.cit. n43, pp.83-4.

${ }^{52}$ Brown and Hesketh, op.cit., n43, p.36.

${ }^{53}$ Id., p.220. See also G. Hinchliffe and A. Jolly, 'Graduate identity and employability' (2011) 37 British Educational Research J. 563 at 578.

${ }^{54}$ Sommerlad, op.cit., $\mathrm{n} 8$.

${ }^{55}$ Id. p.96

${ }^{56}$ Brown and Hesketh, op.cit., n43, p.227.

${ }^{57}$ B. Beagan, 'Micro Inequities and Everyday Inequalities: "Race", Gender, Sexuality and Class in Medical School' (2001) 26 Canadian J. of Sociology, 583 at 600.

58 <http://78.158.56.101/archive/law/projects/current-projects/francis/index.html>

${ }^{59}$ A. Francis and H. Sommerlad 'Access to legal work experience and its role in the (re)production of legal professional identity’ (2009) 16 International Journal of the Legal Profession 63 at 67-9; T. Ginsburg and J. Wolf, 'The Market for Elite Law Firm Associates' (2004) 31 Florida State Law Review 909.
} 
This version was accepted for publication on the $28^{\text {th }}$ January 2015. The definitive version is available at www.blackwellsynergy.com.

This study was designed to enhance our understanding as to the role that legal work experience plays in mediating access to the legal profession and to consider the different ways in which it is constructed and experienced by students and employers. It drew on a mixture of survey and qualitative methods with students and employers. ${ }^{60}$

The student perspective was critical. Not only are students' concerns about employability a major driver for universities, but, Tomlinson argues, students themselves internalise messages about employability. ${ }^{61}$ Questionnaires were distributed to LLB students in the autumn of their second and third years, with focus groups in the spring of their third year, ${ }^{62}$ from a pre-1992 and a post 1992 university. ${ }^{63}$ The profile of the student sample broadly mirrors that of the national cohort. ${ }^{64}$ There are, however, demographic differences between the student bodies at the two institutions; for instance the post-1992 sample contains more students from a BME background and more mature students. ${ }^{65}$

The primary focus in their second year was on the students' informally arranged work experience and the ways in which that positioned them for the formal vacation schemes. The third year survey explored changes in their understanding of legal work experience and its role in the recruitment process. This data was analysed through SPSS. Given the consistency of the responses (on the one hand) and the clear post-92/pre-92 binaries between two institutions (on the other), much of the analysis of this data does not attempt to draw conclusions about aggregated patterns of behaviour. ${ }^{66}$ Nevertheless, cross-tabular analysis was undertaken, and I have attempted to highlight where particularly strong associations arose between variables. ${ }^{67}$

Data from employers was derived from a survey of 50 firms $(26+$ partner firms in the principal legal markets served by the participating institutions). ${ }^{6}$ Detailed interviews were then undertaken with an illustrative sample of 16 Graduate Recruitment Managers and Partners from elite corporate multinationals to 19 partner regional practices. This dataset is subject to the usual caveats about qualitative methods and interviews in particular. ${ }^{69}$ However, my analysis of the interview data was also informed by a wider understanding of the processes and changes within the field, ${ }^{70}$ and it is important to note the consistency between these employer responses with other sources, including wider recruitment

\footnotetext{
${ }^{60}$ Miller et al. SPSS for Social Scientists (2002) 1.

${ }^{61}$ Tomlinson, op.cit. n43, pp.83-4.

${ }^{62}$ Second year response rate was Pre-92: $135 / 280=48$ per cent, Post-92: $135 / 200=67.5$ per cent. In the third year this was 60/280 (21 per cent) pre-92 and 57/200 (28.5 per cent) post-92.

${ }_{63}$ Obviously, the landscape is far more complex than this, but it is a label understood by both the legal education sector and the recruiting firms.

${ }^{64}$ Fletcher, op.cit. n12, p.34.

${ }^{65}$ See also D. Reay, M. David, S. and Ball Degrees of Choice: social class, race and gender in higher education (2005).

${ }^{66}$ Miller et al., op.cit., n60, p.3.

${ }^{67}$ Id, p. 133.

${ }^{68}$ Although, there was a disappointing response of just $16 \%$, the responses do nevertheless accord with other surveys (King's College London, Law Employability Research, in partnership with The Times (2013)) and with the more detailed qualitative data.

${ }^{69}$ D. Silverman, Interpreting Qualitative Data: Methods for Analysing Talk, Text and Interaction (1993) 144170 and 196-211.

${ }^{70}$ D. Layder New Strategies in Social Research (1993) 19
} 
This version was accepted for publication on the $28^{\text {th }}$ January 2015. The definitive version is available at www.blackwellsynergy.com.

material, ${ }^{71}$ other 'careers-type' surveys ${ }^{72}$ and indeed the student data. Nevertheless, where there are different stories, or alternative readings, I have attempted to outline them in discussion. ${ }^{73}$ The focus groups and interviews were subject to thematic analysis, ${ }^{74}$ before coding and identification of key illustrative quotations.

\section{THE CONSTRUCTION OF LEGAL EMPLOYABILITY AND THE IMPORTANCE OF SOCIAL BACKGROUND AND EDUCATIONAL HISTORY}

Law graduates face particular challenges in demonstrating their employability. The graduate market is contracting and there is huge uncertainty about the future of the legal services sector. As is the case in other sectors, credential inflation requires law graduates to demonstrate distinction. Drawing on the research findings, the following section will argue that the habitus forged through social class and educational experience can not only 'frame graduates' perceptions of their own employability and their propensities towards seeking various forms of employment, ${ }^{75}$ but also affect their ability to meet firms' expectations. Crucially, although firms' expectations are presented neutrally - for example 'global mindset, commercial awareness and intellectual rigour ${ }^{76}$ - graduates are not equally positioned in terms of their ability to satisfy these requirements.

In the context of the law firms' construction of an employable graduate identity, ${ }^{77}$ A-Levels feature heavily. In the Work Experience study, all surveyed firms were 'extremely unlikely' to consider grades below BBC and interviewees generally spoke in terms of straight-As, or $\mathrm{ABB}$ at the outside. Firms were also relatively traditional in terms of preferred A-level subjects. Of those students surveyed, 62.3 per cent of post-92 students and 7 per cent of pre1992 students had grades below BBC. In terms of university performance, most firms looked not just for a predicted 2(i), but a 'comfortable 2(i)', with '75 per cent of marks at 2(i) level'. ${ }^{78}$ Yet, we should be cautious about the context in which the generally better educational credentials of those with more traditional backgrounds have been achieved. As Morley argues, 'socio-economic privilege appears to be transferred onto the production and codification of qualifications and competencies, [ensuring that] social gifts are treated as natural gifts. ${ }^{79}$

\footnotetext{
${ }^{71}$ For example as discussed by R. Collier “"Be Smart, Be Successful, Be Yourself”? Representations of the Training Contract and the Trainee Solicitor in Advertising by Large Law Firms' (2005) 12 International Journal of the Legal Profession 51.

${ }^{72} \mathrm{KCL}$, op.cit., n68.

${ }^{73}$ Silverman, op.cit., n69, p.162.

${ }^{74}$ V. Braun and V. Clarke 'Using Thematic Analysis in Psychology'(2006) 33 Qualitative Research in Psychology 77

${ }^{75}$ Tomlinson op.cit. n43, p.86.

${ }^{76} \mathrm{KCL}$, op.cit., n68.

${ }^{77}$ Large corporate firms, recruiting two years in advance, effectively use the same criteria in their selection of Vacation Scheme candidates and Trainee solicitors.

${ }^{78}$ HESA statistics show 64 per cent of undergraduate degrees in Law were at $1^{\text {st }}$ or 2(i) level in 12/13 <http://www.hesa.ac.uk/dox/dataTables/studentsAndQualifiers/download/Qualsub1213.xlsx>. This is an important context for the 'distinction.'

${ }^{79}$ L. Morley 'The X factor: employability, elitism and equity in graduate recruitment' (2007) $221^{\text {st }}$ Century Society 191 at 205; see also P. Brown, 'The "Third Wave": education and the ideology of parentocracy' (1990) 11 Sociology of Education 65 at 77. Firms were open to some mitigation, and were not unsympathetic to issues of socio-economic disadvantage, but generally found it difficult to make adjustments on these criteria. See further L. Ashley, 'Making a Difference? The use (and abuse) of diversity management within the UK's elite law firms', (2010) 24 Work, Employment and Society 711.
} 
This version was accepted for publication on the $28^{\text {th }}$ January 2015 . The definitive version is available at www.blackwellsynergy.com.

Firms were explicit in underlining that they viewed 'such academics' as a starting point, and looked for other means of distinction. ${ }^{80}$ As one employer in Brown and Hesketh's study put it; 'paper qualifications are the first tick in the box and then we move onto the real selection. ${ }^{81}$ The successful students were those who had understood the need for distinction and who had the cultural capital and intellectual ability to demonstrate it. As one student reflected; 'If everyone who's applying have got 2(i)s, it needs to be something that makes you look different' (Female, pre-92, TC National Multi-Departmental). In their study of graduate recruitment Morley et al., identified specific areas of distinction; 'a range of soft skills with considerable attention paid to interpersonal and communication skills. ${ }^{82}$ Thus, in the Work Experience study, the well-rounded personality was valued, as firms felt that it evidenced the ability to operate successfully within a firm, particularly in terms of client interactions - 'personable geniuses' (Female Partner, Large Corporate \#15). However their conception of a well-rounded personality and the ways in which students demonstrate this, also underline the difficulties that face many non-traditional students in seeking to negotiate the professional field, which fundamentally does not expect to see 'the likes of [them]. ${ }^{, 83}$ What, I argue, the data suggests is not a process of formal exclusion but rather, the discomfort that Bourdieu identifies for those lacking the appropriate habitus for a particular social field. ${ }^{84}$

Firms define legal graduate employability through their search for 'the $\mathrm{X}$ factor..., [the applicant] must have, maybe artistic, sporty or whatever, but something that just makes them a little bit more interesting' (Female Grad Recruitment, Regional Multi-Departmental, \#8). It is an indefinable something that marks them out as 'having an effect on things and people' (Female Grad Recruitment, Magic Circle, \#3). While the X factor is presented as bias-free, ${ }^{85}$ in practice students from working class or non-traditional backgrounds will experience differential access to the activities which enable students to demonstrate the $\mathrm{X}$ factor in ways that are readily recognizable to the firms. Thus,

extra-credential experiences can serve powerful social closure functions, while appearing part of a fair and meritocratic process. .... Teamwork, communication and other interpersonal skills are more convincingly demonstrated through relevant employment or volunteer experiences than through outstanding academic records. ${ }^{86}$ Hinchcliffe and Jolly also emphasise the importance of practice and identity in performing graduate employability, but stress that 'it may be that the identity a graduate presents is not recognised... by an employer' ${ }^{87}$

Thus, one firm asks about 'hobbies and interests - we are looking for a blend of solo and team activities - sports, moots, clubs' (Male Graduate Recruitment, National Multi-Departmental, \#9). Another suggested that 'it could be anything; sport, JCR, social clubs, politics or whatever, as long as there's a spark shown' adding that a 'burning ambition to whitewater

\footnotetext{
${ }^{80}$ Firms reported having to deal with 300, 1500, 2000 applications for their training contract programmes.

${ }^{81}$ Brown and Hesketh, op.cit., n43, p.31.

${ }^{82}$ L. Morley et al. Needs of employers and related organisations for information about quality and standards of higher education Report to HEFCE by the University of Sussex School of Education (2006) 74.

${ }^{83}$ Bourdieu, op.cit., n47, p.56.

${ }^{84}$ Id., p.59

${ }^{85}$ Morley, op.cit. n79.

${ }^{86}$ W. Lehmann, 'Extra-credential experiences and social closure: working-class students at university', (2012)

38 British Educational Research J. 203 at 215.

${ }^{87}$ Hincliffe and Jolly, op.cit. n53, p.565.
} 
This version was accepted for publication on the $28^{\text {th }}$ January 2015. The definitive version is available at www.blackwellsynergy.com.

raft on the Amazon' could be a legitimate reason why an applicant had not undertaken work experience (emphasis added) (Male Partner, Magic Circle, \#11). Other interviewees highlighted societies at university, participation in mooting, client interviewing and so on. Fundamentally, there should be breadth. Firms see university as an ideal opportunity for students to engage in a range of extra-curricular activities which would enable them to demonstrate their well-rounded personality. Hinchcliffe and Jolly confirm that 'employers [generally] were often suspicious of graduates who had used their student experience in a narrow way, ${ }^{88}$

All firms were open to a story being told about different types of activities - working in a shop for example, demonstrates commitment, perseverance and perhaps a level of commercial awareness - but it was not what they were expecting to see. However, many non-traditional students are unlikely to realize that they can tell such a story, let alone how they can go about doing so. As one interviewee conceded, 'we've always encouraged, and will continue to do, a strong degree of self-selection in our applications' (Female Graduate Recruitment, Magic Circle, \#3). Without support, many will self-select out of the recruitment process in the face of the mixed messages from firms. As this section has made clear, a close reading of legal graduate employability reveals serious barriers to social mobility aspirations.

\section{LEGAL WORK EXPERIENCE AND ITS ROLE IN ENHANCING EMPLOYABILITY AND SUPPORTING SOCIAL MOBILITY}

Work experience is important not only because it forms part of the narrative of an employable graduate identity, but it is presented as a key neutral strategy through which to enhance employability and address social mobility concerns. The data presented here highlights the difficulties that students from non-traditional backgrounds face in securing these opportunities. Moreover, when we analyse the students' own perception of their work experiences, the notion of work experience as an uncontested employability good is challenged. ${ }^{89}$ In addition, the findings draw attention to the difficulties that are likely to emerge in formally embedding work experience within university employability strategies. ${ }^{90}$ Taken together, I argue this reinforces the importance of class, background and education in the narrative of a legal employability, which is not equally available to all. This challenges mainstream justifications for employability within higher education and highlights the complexity of the challenge of addressing social mobility concerns within the legal profession.

\section{Work Experience - Who gets it and when?}

The significance of 'previous legal work experience' is underlined by the following student. Something that was fairly consistent between those of us who got [vacation scheme] and those who didn't, were the ones who had informal work experience. It was very, very important (Female, Pre-92, TC National multi-departmental).

The firms said that previous informal work experience signals that the applicant has thought seriously about their career. It is part of the picture of who firms expect to see. They expect to see a candidate who has undertaken 'at least three forms of work experience - for instance,

\footnotetext{
${ }^{88}$ Id., p.575.

${ }^{89}$ Dearing, op.cit. n5, p.136. See also Wilson op.cit. n2, p.7 and Mason, et al. op.cit. n5, p.9.

${ }^{90}$ Prior op.cit. n34.
} 
This version was accepted for publication on the $28^{\text {th }}$ January 2015. The definitive version is available at www.blackwellsynergy.com.

I'd encourage them to approach a High Street Firm, or maybe volunteer at Law Centre, or ask around friends and family' (Female Graduate Recruitment, National Multi-departmental, \#6).

The expectation was that students would have friends and family through which they could secure legal work experience. Given that only 8 per cent of the $2^{\text {nd }}$ year sample had ever been refused informal work experience, the importance of knowing when, how and who to ask is clear.

By pure chance and luck I knew one of the practice managers through one of the local theatre groups. At the start I did a couple of days at the end of sixth form, just shadowing different people (Female, Pre-92, TC, National Multi-departmental).

I started ... looking at ways of getting work experience in sixth form because I had a law teacher who one day, said 'yes, legal work experience, very important'. I didn't know why it was, but I thought it was something productive that I could be doing (Male, Pre-92, TC, Large Corporate).

The recruiters stressed that they recognised the challenges involved in securing conventional legal work experience without contacts, and again some were open to a story being told about its absence on a cv. However, such a candidate remains a departure from who they expect to see. Lehmann also notes that, for the working class students in his study, 'it was the internships in medicine and dentistry, the law firm volunteer placements and the international study and work experiences that they desired but that were out of their reach. ${ }^{91}$

By their $3^{\text {rd }}$ year, most students surveyed had continued to secure informally arranged work experience and thus, it could potentially be a valuable resource to draw upon in PDP activities. ${ }^{92}$ Just over half of the sample by this stage had secured at least one period of informally arranged legal work experience. However, the students in the pre-92 institution were far more likely to have attempted to secure legal work experience - 80 per cent in contrast to 47.4 per cent. ${ }^{93}$ In second year, the most common reason for not having undertaken work experience was 'Didn't know how to arrange it', and the post-92 students were twice as likely as the pre-1992 students to give this as their reason. 'Didn't think of it' and 'too nervous' to apply were also responses which the post-92 students were more likely to record. There is potential for raising awareness about the value and role of legal work experience within all Law Schools, but as we will see below, this is not straightforward.

Vacation schemes not only act as an integral stage in a firm's recruitment processes, but also as part of the developing narrative of a student on a pathway towards establishing an employable graduate identity. Recruiters ask 'why not?' if there is no formal vacation scheme on an application for a training contract. Despite the largest firms recruiting two years in advance, only just under half (45.3 per cent) of the sample had applied for a Formal Vacation Scheme by the November of their third year. Although this shift from the 81.2 per cent who were focussed on becoming either solicitors or barristers in the autumn of their second year ${ }^{94}$

\footnotetext{
${ }^{91}$ Lehmann, op.cit., n86, p.14.

${ }^{92}$ HEA op.cit. n32.

${ }^{93}$ With only two institutions surveyed it would be invidious to make broader conclusions, but the difference was significantly greater than that would be achieved by chance. Cross-tabular analysis generated an adjusted residual of 3.2. This is the difference between the expected and observed frequencies. Accepted practice gives special attention to values greater than 2 or less than -2 (Miller et al., op.cit. n60, p.133).

${ }^{94}$ See similar results in Hardee op.cit. n36
} 
This version was accepted for publication on the $28^{\text {th }}$ January 2015 . The definitive version is available at www.blackwellsynergy.com.

is not unsurprising, given what is generally assumed about law graduate destinations, ${ }^{95}$ it is worth noting the institutional differences. Students from the pre-92 institution were, once again, much more likely to have applied for a Formal Vacation Scheme. Just 29 per cent of the post-92 institution's students had applied, compared to just over 60 per cent of the pre-92 institution students. Moreover, the pre-92 students were more likely to have made multiple applications. Thus, of those students who had made 2-3 applications for vacation schemes, it was evenly spread between institutions. Of those who had made more than 5 applications (thus increasing their chances of success), they were overwhelmingly from the pre-92 cohort. $^{96}$

This data strengthens my argument that legal graduate employability is constructed by the recruiting firms as a narrative that is enacted, ${ }^{97}$ rather than a set of skills and attributes that can be taught and acquired. Crucially, an individual's habitus shapes their ability to intuitively recognise and comfortably access the opportunities to develop this narrative. Work experience is a crucial dimension of this process. Thus, those who were successful in securing Formal Vacation Schemes all possessed multiple episodes of informally arranged work experience and were far more likely to attend the pre-92 institution (25 per cent of these students had Formal Vacation Schemes compared to 3.5 per cent of post-92 students). In addition, the vast majority ( 88 per cent) had A-level grades of $\mathrm{ABB}$ or better, and, barring two exceptions, presented a 2(i) degree profile. Firms' assessment criteria (common to both training contract and vacation schemes) map clearly onto those patterns of student success. ${ }^{98}$

Students with connections to the profession through either family or friends were twice as likely to have secured Work Experience at an early stage (year 10/11) than those without such connections. Overall, students were more likely to have had work experience than not, except those students whose fathers worked in 'routine and semi-routine occupations. ${ }^{99}$ In her analysis of North American law and business schools, Schleef identities the inevitability, or 'default' nature of participation in professional education among privileged middle class students. ${ }^{100}$ Brown also highlights what he describes as 'parentocracy', where the 'education [or professional opportunities] a child receives... conform[s] to the wealth and wishes of the parents, rather than the abilities and efforts of pupils. ${ }^{, 101}$

The path to a training contract is not as inevitable as enrolment in a professional school, ${ }^{102}$ but it is still infinitely more comfortable for middle class law graduates. Their habitus has, as Bourdieu puts it, enabled the 'ease of a comfortable situation ensuring an easy life," 103 through which they secured the opportunities to develop the narrative of legal employability. Of course, university law schools could attempt to make work experience widely available as one way to redress the problems of differential access highlighted above. However, the following section, which challenges the idea of legal work experience as a neutral learning

\footnotetext{
${ }^{95}$ Hunt The Hunt Review of Legal Services (2009) 89.

96 The most common reason (across both institutions) for not applying was that they did not think that their academic profile was strong enough.

${ }^{97}$ Brown and Hesketh op.cit. n43, p.36.

${ }^{98}$ Francis and Sommerlad, op.cit. n59, p.75.

${ }^{99}$ The occupational categorization followed that used by the Office for National Statistics <www.ons.gov.uk/about-statistics/classifications/current/ns-sec/cats-and-classes >

${ }^{100}$ D. Schleef, Managing Elites: Professional Socialization in Law and Business Schools (2006) 200.

${ }^{101}$ Brown, op.cit., n79, p.65.

102 Schleef, op cit., n100.

${ }^{103}$ P. Bourdieu, Distinction (1984) 255-6.
} 
This version was accepted for publication on the $28^{\text {th }}$ January 2015 . The definitive version is available at www.blackwellsynergy.com.

opportunity, will draw out the difficulties in translating all of the benefits associated with legal work experience into the curriculum.

\section{Experiencing Work Experience: Learning to Learn and Learning to Fit in}

I argue that the research findings about the processes of legal work experience challenge 'taken for granted' assumptions about work experience. They indicate that work experience operates as a cultural marker of distinction, a process of transformation and assessment and far less as a neutral arena within which technical skills and attributes are developed. Student experiences can, of course, be a powerful learning and teaching resource. ${ }^{104}$ However, the value is heavily contingent upon the nature of those experiences. What actually happens during work experience, whether informally arranged or as part of a formal vacation scheme is crucial to understanding firms' constructions of the employable graduate.

The vast majority of students were overwhelming positive about their informal work experiences. For many, it had been critical in fuelling their desire to study law, which is of huge value if greater access to informal work experience is made available to students who may not be convinced that the pathway is right for them. From a social mobility perspective, timing will be critical in ensuring that students know about these opportunities and how to access them in order to maximise the value of the experience. Yet, there was also evidence that students learned something of the realities of practice; it could be competitive, it was extremely busy and, just very occasionally, legal work was not necessarily terribly exciting.

Overall impression was that is a hard profession to work in at times. However very rewarding at other times (Female, Post-92).

Boring as involved Land Law, but well paid (Male, Pre-92).

These are valuable insights which can assist students in making informed decisions about their careers. ${ }^{105}$ Moreover, if students are able to develop insight into how to operate within the firm it is likely that they will find themselves better able to deal with firms' expectations in the formal recruitment processes. However, in terms of specific technical skills and attributes that the recruiting profession will require, it is unlikely that informal work experience can deliver much in terms of informing student learning.

The nature of their work was not particularly detailed or complicated. Moreover, as students moved along the pathway to success, their view of the value of the experiences became more cynical.

.... the big firm in London doesn't give two hoots about the experience you've had with the criminal defence firm in [name]. But they can see you're the right sort of person and have made the effort (Male, TC, Pre-92, Large Corporate)

There is also a disconnect between the smaller high street sector within which most students secured their experience, ${ }^{106}$ and the fact that vacation schemes and training contracts are typically offered by the larger firms, ${ }^{107}$ As one student put it 'my informal work experience at high street firms, ..., I don't think it really gave me an actual insight into the day to day what I

\footnotetext{
${ }^{104}$ G. Light and R. Cox, Learning and Teaching in Higher Education: The Reflective Professional (2001) 79.

${ }^{105}$ Watts, op.cit. n4.

${ }^{106} 62.5$ per cent (at Level 3) had experience in this sector, compared to 15 per cent in corporate sector.

${ }^{107}$ Francis and Sommerlad op.cit. n59, p.71; 36.8 per cent of traineeships were registered in $81+$ partner firms , with 38 per cent in the City (Fletcher, op.cit. n12, pp.44-6).
} 
This version was accepted for publication on the $28^{\text {th }}$ January 2015 . The definitive version is available at www.blackwellsynergy.com.

would be doing if I was working at a bigger firm' (Female, pre-92, TC), which is understandable, given the scale of fragmentation within the profession. ${ }^{108}$

In direct contrast, learning (and the assessment of learning) is an explicit objective of Formal Vacation Schemes. They are highly structured, designed to assess the candidate and give a realistic insight. ${ }^{109}$

What they do on the vacation scheme, when you join as a trainee this is exactly the sort of stuff you will be doing almost immediately.....So it does become quite an interesting test when you know more or less this is what they're going to be like on day one (Male Partner, Large Corporate, \#16).

For a number of the firms, the assessment is focussed on the final interview for the training contract that takes place at the end of the vacation scheme. For others, this assessment will also be informed by formal reports from those supervising the vacation schemer's work, or more informal assessments from those who have interacted with the student (including existing trainees); 'They are here to shine and we don't want to sound too Big Brotherish, but they are assessed' (Female Graduate Recruitment, Magic Circle, \#1).

A key part of what firms say they assess is the capacity to be self-aware, reflexive, and able to quickly understand what is being sought. ${ }^{110}$ The students need to learn about the tasks that they have been asked to complete, be enthusiastic about those tasks and indicate that they can model the trainee approach to work more generally - 'by not running out the door at 5.30' (Female Graduate Recruitment, Large Corporate, \#4), and thus embracing the 'total institution' of a large corporate law firm. ${ }^{111}$ It is an explicit process of transition and 'part of the transition [on a work placement] is their willingness to understand that there is a transition [between academic work and the profession]. And that will be part of the assessment' (Female Partner, Large Corporate, \#15).

The work that firms organise is designed to test this. The majority of students responding indicated that most of their time on their Formal Vacation Scheme had been spent on structured research projects. They were positive about the work, with 68 per cent either agreeing or strongly agreeing that 'I got a really good exposure to the type of work I'd be doing as a trainee.' Thus students might do 'a piece of research, go to a meeting, draft a letter to a client' (Female Graduate Recruitment, Large Corporate, \#4).

Firms look for reflexivity; the ability to learn from feedback, improve and change.

I always pose the question ... [on the] last day, 'do you feel, or how much do you feel, you've changed as a person, in terms of your skills and your self-awareness, and your knowledge about yourself, as well as about this, over four weeks?' (Female Graduate Recruitment, Magic Circle, \#2)

In one firm I was asked to draft a letter and had some feedback that said I 'sounded like a lawyer from the 16th century, so cut out some of these fancy words.' So the next letter I wrote I tried a more clear professional style and they said 'good, you've learned from the feedback.' (Male, pre- 92, TC Large Corporate)

\footnotetext{
${ }^{108}$ A. Francis At the Edge of Law: Emergent and Divergent Models of Legal Professionalism (2011) 3.

${ }^{109}$ See similarities in U.S., Ginsburg and Wolf op.cit. n59.

${ }^{110}$ Sommerlad, op.cit. n8

${ }^{111}$ E. Goffman Asylums: Essays on the Social Situation of Mental Patients and Other Inmates (1968) 11 and

Collier, op.cit. n71, p.67.
} 
This version was accepted for publication on the $28^{\text {th }}$ January 2015 . The definitive version is available at www.blackwellsynergy.com.

However, operating successfully in the first place and then being able to learn reflexively is likely to be easier if you have advance understanding of the learning tasks ahead and what will be expected of you during these processes. ${ }^{112}$ Although most students in their second year had a broad understanding of the role, purpose and importance of formal vacation schemes within the recruitment processes of large firms, 24.4 per cent thought that 'general mentoring /providing insight' formed part of firms' motivations. Cross-tabular analysis identifies a strong association between this lack of understanding, 'not having had legal work experience' and attendance at a post-92 institution, which is indicative, at least, of some students' struggles to enact the narrative of legal employability. ${ }^{113}$ Even by their $3^{\text {rd }}$ year, most students maintained their insistence that demonstrating 'good legal knowledge' was the most important characteristic that a good Vacation Scheme student should demonstrate. This was far less important for the firms.

The graduate recruitment team said to me [after I've been offered a Training Contract], sometimes ... the way you conduct yourself [over the two week period] that's more important than perhaps the answers you give in the interview or the brilliant role play you did (Female, pre-92, TC National Multi-departmental).

I argue that firms' expectations that the prospective trainee will 'fit' comfortably and engage effectively with clients reinforce the importance of habitus within legal practice. ${ }^{114}$

Successful applicants are those whose habitus equips them with an instinctive understanding of how to play the game. ${ }^{115}$ Firms expect students to demonstrate 'enthusiasm', 'common sense', an 'ability to interact', and echoed this summary, 'We're really looking for people who are happy to get involved - the more involved they are, the stronger their report will be.' (Male Graduate Recruitment, National Multi-departmental, \#9). As Hinchcliffe and Jolly confirm, in another employment context, 'the graduate must be able to fit quickly into a team and if this attribute is lacking they may not get appointed even if their technical skills are highly developed. ${ }^{116}$ Firms are assessing (whether continuously, covertly or at the formal interview) that prospective trainees can instinctively fit and embody the employable graduate identity.

Firms' examples of what they looked for in dress included no 'tongue bars', no 'short skirts' and for the men to be 'clean shaven and wear black shoes not brown,' and sometimes ask trainees to score students on their appearance. The process of adjustment in dress, also underlines the transformations that recruiters are looking to see.

They now need to have the mentality of imagining you're now a city lawyer. Imagine what that looks like and feels like.... And the hairstyle and shoes is part of that... If after a week, you don't understand what is expected in a law firm, on the assumption that you're reasonably intelligent and have an interest in Law, then the alarm bells do go off (Male Partner, Large Corporate, \#16).

Appearance and dress is part of the evaluation as to whether applicants understand what is required of them in a professional environment and possess an intuitive and 'practical mastery... of their situation. ${ }^{117}$ Critically however, this reflexive project of the self is framed

\footnotetext{
112 A. Brockbank and I. McGill Facilitating Reflective Learning in Higher Education (2000) 61-2.

${ }^{113}$ This form of analysis does not demonstrate a causal relationship, but does indicate a pattern consistent with the picture of marginalisation borne out elsewhere in the data.

${ }^{114}$ Bourdieu, op.cit. n47, p.59

${ }_{115}^{15}$ B. Fowler, Pierre Bourdieu and Cultural Theory: Critical Investigations (1997) 18.

${ }^{116}$ Hinchcliffe and Jolly, op.cit. n53, p.572.

${ }^{117}$ D. Robbins, The World of Pierre Bourdieu: Recognising Society (1991)1.
} 
This version was accepted for publication on the $28^{\text {th }}$ January 2015. The definitive version is available at www.blackwellsynergy.com.

as an individual's responsibility and ignores the importance of social and cultural background in supporting an individual's capacity to successfully engage in this project. ${ }^{118}$

There is an economic rationality to firms' expectations of their recruits to look the part of the 'city lawyer' to reinforce client confidence, and to hire lawyers who are sufficiently attuned to their environment to make appropriate adjustments, whether that is in terms of their execution of work tasks, appearance or even knowing that drinking with clients is not the same as drinking with their friends. The difficulty is that those from more disadvantaged backgrounds may find it difficult to engage in reflexivity from a position of marginalisation. ${ }^{119}$ Earlier and frequent exposure to informal periods of work experience and longer term engagement in professional classes ${ }^{120}$ is likely to assist prospective graduates in developing this understanding, and the absence of such opportunities to develop professional self-awareness 'may further disadvantage such lower status groups in social and economic terms. ${ }^{121}$ Thus, those who had had legal work experience by their second year, were slightly more likely than those without such experience to predict that 'appearance/dress' could be a dimension of negative performance on a formal vacation scheme, and students in the focus groups reflected on their anxiety of 'having only one suit'. In contrast, students reported that many of the other prospective trainees had been rehearsing the role of city lawyer for some time; 'A few people already sort of knew each other and they were all strutting and joking about the squash ladder and all the rest of it. Very much moulding themselves into the City boy attitude already' (Male, pre-92, TC, Large Corporate). As Bauman puts it, their backgrounds equipped them with an ability of intuitively 'knowing how to move in the world. ${ }^{122}$

Fundamentally, while work experience is a key feature of the narrative of success, I have argued that students already possessing socio-economic advantages are more likely to secure work experience in the first place. It is not a neutral opportunity which all prospective entrants can access and experience in the same way. Although work experience is a process of identity formation for all students (to varying degrees) - of becoming someone new in the social field - unlike Turner's 'liminal' subjects, the vacation schemers do not sit outside social structures. ${ }^{123}$ Rather, they are deeply constrained within these structures during this process, by virtue of their pre-existing dispositions. ${ }^{124}$ Not all actors are equally capable of demonstrating the required transformation.

It's not ingrained, there's not an automatic mechanism for a lot of people...The vacation placement may be, for some, their first view of the outside world in a business context ... loads of people, ... are hugely naive about the world, and perhaps a lawyer's role in it... (Male Partner, Large Corporate, \#16).

\section{CONSTRUCTING LEGAL EMPLOYABILITY WITHIN A UNIVERSITY LAW SCHOOL}

\footnotetext{
${ }^{118}$ Brown and Hesketh op.cit. n43, p.220, Hinchcliffe and Jolly, op.cit. n53, p.578

${ }^{119}$ Z. Bauman, 'Chasing Elusive Society' 18 International J. of Politics, Culture and Society (2005) 123 at 135.

${ }^{120}$ Schleef op.cit., n100, pp.23-24; F. Anderson-Gough, C. Grey and K. Robson 'Professionals, Networking and the Networked Professional' (2006) 24 Research in the Sociology of Organizations, 231 at 239.

${ }^{121}$ P. Sweetman, 'Twenty-First Century Dis -ease? Habitual Reflexivity or the Reflexive Habitus, (2003) 51

Sociological Review 528 at 544.

${ }^{122}$ Bauman, op.cit. n119, p.134.

${ }^{123}$ V. Turner Dramas, Fields and Metaphors: Symbolic Action in Human Society (1974) 231-2.

${ }^{124}$ Bourdieu, op.cit. n47, p.56
} 
This version was accepted for publication on the $28^{\text {th }}$ January 2015 . The definitive version is available at www.blackwellsynergy.com.

In this section, I argue that there are also deep-rooted structural constraints upon Law Schools' ability to support student employability in readiness for this transition. Of course, there is a legitimate question as to whether Law Schools should do this at all. However, in critically analysing what is being done in the name of employability within legal education, we can engage in a critical, but constructive, dialogue with the legal profession, bring greater scrutiny to bear on objectively neutral processes of recruitment and, indeed, critique wider sector and policy claims about employability.

Of course, higher education does have a clear relationship with graduate employment. While large numbers of law students progress to careers in a range of other sectors, the legal profession remains the largest single sector and it is one to which most students aspire (at the outset at least). Mid-way through their second year, 63.8 per cent wanted to be solicitors with 17.8 per cent aiming for the Bar. Although the broad orientation towards a career in the legal profession was sustained into their third year, there were some shifts. Thus, although those aiming to become solicitors had dropped overall to 57.3 per cent, the growing awareness of the competitive marketplace appeared to affect each cohort differently. For the pre-92 students this appeared to indicate consideration of the solicitor route than the Bar, whereas for post-92 students it meant other career options entirely. ${ }^{125}$

As indicated in the previous section, there were gaps in student understanding and these were marked by differences on the basis of prior exposure to professional settings and forms of cultural capital, with institution attended often operating as a proximal marker. Despite widespread adoption of the employability agenda within legal education there has, to date, been relatively little analysis of its limits. The following section addresses this gap and argues that legal employability is not only contingent upon its construction by recruiters (see above), but on the field location of the institution and the strength of the 'Possible Self' of students. This motivation for students to take steps to enhance their social or human capital is not uniformly available - and for the privileged, not even necessary.

Some Law Schools have embedded professional skills and employability modules directly into the undergraduate curriculum. ${ }^{126}$ Such modules potentially help students develop their knowledge and understanding of what is required. Legal education has also seen attempts to help students translate their experiences into what the profession might find valuable recognising, for example, that there is a story to be told from the part-time employment in a supermarket. PDP is designed to enable students to reflect on skills, achievements and goals in a structured way. ${ }^{127}$ Yet the dangers are that this is framed in the narrow, de-contextualised manner characteristic of the broad employability agenda. Clegg cautions that QAA guidance on PDP assumes that 'these capacities [enhanced through PDP] are all designated as personal and residing within the individual, rather than the structured powers and tendencies that

\footnotetext{
${ }^{125}$ See also Lehmann, op.cit n86, p.214.

${ }^{126}$ For example, R. Simmons 'City University introduces compulsory 'employability' module to LLB' (2014) $<$ http://12b.thelawyer.com/courses/undergraduate/city-university-introduces-compulsory-employability-moduleto-llb/3019606.article>

${ }^{127}$ S. Bloxham and A. Cerevkova 'Reflective Learning, Skills Development and Careers Management OnlineAn Evaluation of a First Year Law Module' (2007) 1 J. of Information, Technology and Law (online); R. East 'A progress report on progress files: The experience of one higher education institution' (2006) 6 Active Learning in Higher Education 160; HEA op.cit. n32, p.12.
} 
This version was accepted for publication on the $28^{\text {th }}$ January 2015 . The definitive version is available at www.blackwellsynergy.com.

might make their realisation more or less possible for different groups of students with differentiated access to social and cultural capital. ${ }^{, 28}$

Work placement modules, which involve students securing clinical experience as a core part of their degree, are another strategy which seeks to address employability and social mobility concerns directly within a programme. ${ }^{129}$ Learning through experiences can be an effective way to develop knowledge and skills. ${ }^{130}$ However, in terms of the transformation of the employability of students from all backgrounds, the value of what is learnt will depend on the work to which they are exposed, the ability of the students to identify what they are learning and, ultimately, the preparedness of the profession to recognise any distinction that such initiatives may bring.

The differentiation in the legal education sector, ${ }^{131}$ characteristic of an expanded HE sector, ${ }^{132}$ is critical to the construction of legal employability. This is borne out by the regard in which legal recruiters hold the status of degrees awarded by different Law Schools. Thus, the Law Society recommended that steps be taken to encourage the 'removal of value judgements about institution attended." 133 Institution attended remains a key part of the graduate recruitment strategy of the largest law firms and operates as an important process of classification and distinction ${ }^{134}$ :

We have a number of universities. 13 this year, that we have gone out to and have a more active on-campus presence. And they traditionally, well they are more of your redbrick ones and ones renowned for strong academics. No [former polys]. (Female Graduate Recruitment, Large Corporate, \#4).

Students outside these networks do not get access to the 'enhanced employability' of careers sessions delivered by a recruiting firm. Moreover, and potentially more significantly, it also undermines the employability efforts of such Law Schools for their students. Regardless of how many PDP modules have been undertaken, or how well their 'commercial awareness' has been assessed in a credit-bearing module, if their institution is not deemed as having the appropriate 'resonance in the air' or capable of delivering comparable quality of degree, then the students' employability will only have been enhanced in an extremely limited manner. ${ }^{135}$ As Brown and Hesketh put it 'such activities will typically be seen as "compensatory": an attempt to make up for the personal and social deficiencies that set them apart from the talent

\footnotetext{
${ }^{128}$ S. Clegg 'Critical readings: progress files and the production of the autonomous learner' (2004) 9 Teaching in Higher Education 287 at 289.

${ }^{129}$ For example, an assessed 'Work Placement module' at the University of Westminster http://www.ukcle.ac.uk/resources/employer-engagement/lawschools/. See also D. Gill, 'Self-reflection, selfconfidence and the non-traditional student' (2014) Unpublished conference paper, WG Hart Legal Workshop 2014.

${ }^{130}$ F. Bloch 'The Andragogical Basis of Clinical Legal Education' (1982) 35 Vanderbilt Law Review 321; D. Kolb Experiential Learning (1984).

${ }^{131} \mathrm{~J}$. Webb, 'Post-Fordism and the Reformation of Liberal Legal Education' in The Law School-Global Issues, Local Questions, ed. F. Cownie, (1999), at 228, 232, and 237.

${ }^{132}$ Brown and Hesketh op.cit. n43, p.29.

${ }^{133}$ Law Society Legal Education and Training Review: Response to Discussion Paper 02/2012 (2012) 9. The steps proposed suggested that the Law Society had some sympathy for these concerns.

${ }^{134}$ Bourdieu, op.cit., n103, pp.479-82.

${ }^{135}$ Moorhead considers the experience of a U.S. Law School which implemented various employability strategies into its curriculum only to see its graduate destinations statistics collapse. He poses the question whether narrow vocational employability is really what employers want.

$<$ http://lawyerwatch.wordpress.com/2013/06/27/letr-ii-employability-may-not-be-what-really-employerswant/>.
} 
This version was accepted for publication on the $28^{\text {th }}$ January 2015. The definitive version is available at www.blackwellsynergy.com.

in top Universities. ${ }^{136}$ Thus, graduates' social and cultural capital is further weakened by the institution's reputational capital. Such institutional capital, through the relative standing of different Law Schools, is powerfully reinforced on websites such as 'The Student Room'.

Moreover, I argue that, because of this, the very act of emphasising such employability strands could denote a particular institution as one precisely in need of providing such compensation - 'bronze...inauthentic' institutions in Archer's terms. ${ }^{137}$ It is striking to note that all of the case-studies within Pegg et al. came from the post-92 sector. While work experience credit-bearing modules might be valuable in terms of student enjoyment and selfconfidence, ${ }^{138}$ they are unlikely to be viewed as carrying the same cultural capital as traditional forms of legal work experience. ${ }^{139}$ The problem of 'acceptable work experience', rather than 'experience, born of necessity' is an issue which acutely faces part-time law students. ${ }^{140}$ Legal recruiters instinctively saw traditional informal work experience as signalling 'commitment', rather than valuing it for skills and attributes which might equally be developed in credit bearing modules. What is learnt on anything other than the firm's own formal vacation scheme is not valued; 'I found that every single firm that did ask me about my informal work experience, none of them asked me what I had done. They never asked me what I had learnt' (Male, Pre-92, TC Large Corporate).

The weakened reputational capital of particular institutions may have an additional, negative effect on the self-worth of non-traditional students, and indeed their ability to draw successfully upon their 'Possible Self.' Employability literature stresses the need for students to connect their current studies to their future employment. An effective conception of legal employability has, therefore, to include reference to students' possible selves. Markus and Nurius define possible selves as 'individuals' ideas about what they might become, what they would like to become and what they are afraid of becoming'. ${ }^{141}$ Stevenson and Clegg consider the ways in which students are able to connect current activities to 'their future, possible selves... as employable subjects'. ${ }^{142}$ In this context, the motivational dimensions of the future, possible self are emphasised. Thus, positive emotions about the future self can increase an individual's efficiency and creativity in the achievement of their goals. ${ }^{143}$

Markus and Nurius identify possible selves as incentives for current behaviour, ${ }^{144}$ (for example participation in networking events. ${ }^{145}$ As Stevenson and Clegg highlight, 'students who have highly elaborated possible selves are more likely to aim higher, set clear goals, persist in the face of challenges to their possible self, achieve academically, set higher career

\footnotetext{
${ }^{136}$ Brown and Hesketh, op.cit. n43, p.219.

${ }^{137}$ L. Archer 'Diversity, equality and higher education: a critical reflection on the ab/uses of equity discourse within widening participation' (2007)12 Teaching in Higher Education 635 at 641.

${ }^{138}$ Gill, op.cit., n129.

${ }^{139}$ See also Morley op.cit. n79, p.201 on employers' devaluation of work experience undertaken for financial reasons.

${ }^{140}$ A. Francis and I. McDonald 'After Dark and Out in the Cold: Part-time Law Students and the Myth of "Equivalency"' (2009) 36 J. of Law and Society 220 at 239.

${ }^{141}$ Markus and Nurius, op.cit., n9, p.954

142 J. Stevenson and S. Clegg, 'Possible selves: students orientating themselves towards the future through extracurricular activity' (2011)37 British Educational Research J. 231 at 232.

${ }^{143}$ Id. p.233.

${ }^{144}$ Markus and Nurius, op.cit., n9, p.965.

${ }^{145}$ D. Manderson and S. Turner 'Coffee House: Habitus and Performance Among Law Students' (2006) 31 Law and Social Inquiry 649 at 653.
} 
This version was accepted for publication on the $28^{\text {th }}$ January 2015. The definitive version is available at www.blackwellsynergy.com.

goals and put actions into place to achieve them. ${ }^{146}$ The difficulty is, of course, that all possible selves are not uniformly available to all. ${ }^{147}$ Possible selves can only include those selves that it is possible for that individual to perceive. I argue that those students who were most constrained by their present circumstances and focussed only on surviving the present were those from more disadvantaged backgrounds. They lacked the family support that Brown argues has been critical to the reinforcement of middle class achievement and status over the generations. ${ }^{148}$ The inability to perceive possible selves and thus, use this to motivate and construct employability work appears to be a powerful limitation on the ability of Law Schools to put into place transformative employability agendas for the benefit of all their students. Partial interventions such as 'work experience' will struggle to challenge structural constraints.

A striking theme, from both firms and students, was that students did not engage sufficiently with the employability opportunities that were available; 'when we've done [new universities] in the past, the volume of people has been very poor - it just hasn't been worth the cost of taking the lawyers out of the business' (Male Partner, Magic Circle, \#11). This exacerbates firms' expectations about the type and quality of students with which they will engage. It is difficult to be surprised that students do not have a particularly well developed conception of their potential site of future employment, when many aspects of their future lives are ill-formed or subject to negative signals from the profession. ${ }^{149}$ Moreover, in the context of economic downturn, the risks associated with further study are likely to weigh heavily on these students. ${ }^{150}$ Some of the successful students reflected on the reasons why others were not engaging,

I think [a kind of fear] is a fair way of describing a lot of people's attitudes. It's like they apply but don't want to open the letter (Male, pre 92, TC Large Corporate).

The people who say that [there are no jobs] are normally the ones who haven't done anything... Some of my friends who didn't apply have no idea what they want to do (Female, pre 92, TC National Multi-departmental).

The difficulty however, is that the construction of one's future self - what enables one to see that, for example, a career in the legal profession might be 'possible' - will be dependent, as Bourdieu argues, upon one's past experiences that construct the sense of future possibilities. ${ }^{151}$ The successful students were sufficiently reflective to identify the strong foundations that their own backgrounds had brought them - particularly in terms of securing access to informal legal work experience; 'I had a bit of boost and fortune at the very foundations of my career... If you prepare yourself [or are able to prepare yourself], it's not a harsh reality you're going to be facing, but just the next stage in life' (Male, pre 92, TC large corporate). Fundamentally, because many students from non-traditional backgrounds have not been able to prepare themselves (indeed may find it very difficult to ever to do so), a future in the legal profession is not just the next stage and, thus, their possible self cannot be effectively enlisted to drive motivations for current employability work. ${ }^{152}$ Lehmann notes

\footnotetext{
${ }^{146}$ Stevenson and Clegg, op.cit., n142, p.235.

${ }^{147}$ Bourdieu, op.cit., n47, p.68.

${ }^{148}$ Brown, op.cit., n79.

${ }^{149}$ See data above which highlights the ways in which the students' abilities to successfully enact the legal graduate identity were deeply stratified on institutional and class lines.

${ }^{150}$ C. Callendar and J. Jackson, 'Does the fear of debt constrain choice of university and subject of study?' (2008) 33 Studies in Higher Education 405.

${ }^{151}$ Bourdieu, op.cit, n47, p.68.

${ }^{152}$ Markus and Nurius, op.cit., n9, p.965.
} 
This version was accepted for publication on the $28^{\text {th }}$ January 2015. The definitive version is available at www.blackwellsynergy.com.

that many students re-appraise their career goals as fear grows about their capacity to realise previously held aspirations. ${ }^{153}$

\section{CONCLUSION: POSSIBLE SELVES AND THE CHALLENGE OF DISTINCTION FOR LEGAL EDUCATION}

Recognising the uncertainty of the future possible self for students from non-traditional backgrounds is critical for a nuanced understanding of legal employability. For more privileged students the future is knowable, but for many first-generation participants attendance at university has not only already exceeded familial/social expectations but may generate tensions with those expectations. ${ }^{154}$ The future self beyond this is unknowable and unsettling and, as such, lacks purchase in motivating students to avail themselves of the support that is available within institutions. There is an opportunity for individuals to construct their own employability (and for HEIs to support them in so doing) but crucially, this is "not in the context of their own choosing. ${ }^{155}$ It is done so "within a wider societal context of opportunities and constraints. ${ }^{156}$ This paper has argued that there are fundamental tensions in seeking to align the employability and social mobility agendas to the advantage of all students seeking a career in the legal profession. Moreover, access to, and participation in work experience opportunities on their own is unlikely to transform a student's employability or increase their social mobility precisely because it leaves untouched the fundamental constraints shaping access to the legal professions.

Although this is not the primary focus of this paper, a number of strategies could be deployed. LETR recommends that access to all informally arranged work experience is placed on a similar basis to Formal Vacation Schemes. ${ }^{157}$ This seems unlikely to gain much traction when the informal market of 'work experience favours' traded between friends within different professional service sectors, or to enhance the business profile of the firm, seems entrenched. ${ }^{158}$ At the very least, an alternative scheme, perhaps partnering groups of firms with university law schools and their outreach networks, could provide access to experience designed primarily for exposure and education rather than assessment. There may also be other effective learning and teaching approaches. However, they must be developed not only with an understanding of legal employability as a complex, negotiated and situated process, but through sharing this conception of employability with students.

Employability and social mobility are, in different ways, unspoken threads flowing through the LETR recommendations, and have been a significant theme in the regulators' responses. ${ }^{159}$ Alternative pathways to qualification (and indeed new roles within legal services) are interesting proposals and further complicate traditional constructions of legal employability and the ability of students from different socio-economic backgrounds to successfully demonstrate it. However, their potential as a vehicle for delivering social mobility may be over-stated. Alternative pathways to qualification have always existed (for

\footnotetext{
${ }^{153}$ Lehmann, op.cit. n86, p.214.

${ }^{154}$ D. Reay, 'A Risky Business? Mature Working Class Women Students and Access to Higher Education' (2003)15 Gender and Education 301, B Read et al., 'Challenging Cultures: student conceptions of 'belonging' and power at a post-92 university' (2003) 28 Studies in Higher Education 261.

${ }^{155}$ Brown and Hesketh, op.cit., n43, p.227.

${ }^{156}$ Id., p. 226

${ }^{157}$ LETR op.cit. n1, para 6.55-6.58.

${ }^{158}$ Francis, op.cit., n108, pp.50-1.

${ }^{159}$ SRA, op.cit., n41
} 
This version was accepted for publication on the $28^{\text {th }}$ January 2015. The definitive version is available at www.blackwellsynergy.com.

example legal executives ${ }^{160}$ ) with little transformational impact. There are real concerns about the emergence of a two or three tier legal profession, stratified by background rather than function. ${ }^{161}$ The firms, universities and individuals who do not need to explore alternatives will not do so - and those that do, will automatically denote themselves as less than. ${ }^{162}$ Of course, in developing our theoretical understanding about the complex relationship between social mobility and the legal profession, we cannot disentangle the discussion from debates about society's priorities around child poverty, wider political and fiscal settlements and fair educational opportunities for all.

Legal employability has to take account of the differential access that students from less advantaged socio-economic backgrounds have to the resources that will enable them to become not just employable, but employed as a member of the legal profession. I have argued that the variable student understanding of the subtle messages that they have to grasp in order to successfully negotiate the legal professional field means that 'employability' should not be read simply as an outcome to which students work towards. While agency is possible within Bourdieu's framework, ${ }^{163}$ what is required within specific fields is not necessarily either intelligible to or demonstrable by graduates from particular backgrounds, or who have attended particular educational institutions. ${ }^{164}$

One of the crucial lessons from this paper is the importance of 'additionality'. There is limited value in compulsory credit-carrying 'cultural capital'. Firms are looking for applicants who stand out. Students, particularly those from non-traditional backgrounds, need to be supported in understanding this and then in accessing opportunities, but it does need to come from them. The data presented here provides compelling evidence that work experience is not the magic bullet to address employability and social mobility.

Earlier research highlighted the difficulties that women experience in demonstrating the 'commitment' required for partnership and that initiatives such as flexible working and maternity leave do not deliver the anticipated benefits. ${ }^{165}$ I have argued that 'legal employability' is similarly constructed in such a way that even opportunities and initiatives, such as work experience or other curriculum interventions, designed to strengthen the employability of all graduates irrespective of background, are likely to be experienced differentially. The challenge is to maintain constructive debate with the profession, to develop critical readings of employability for our students and to acknowledge the structural constraints in which opportunities are seized and lost.

\footnotetext{
${ }^{160}$ A. Francis, “'I'm Not One Of Those Women's Libber Type People But ...”: Gender, Class And Professional Power Within The Third Branch Of The English Legal Profession' (2006) 15 Social and Legal Studies 475.

${ }^{161}$ However, we do need to recognise that changes in legal practice are likely to see a greater diversity of roles within legal services. The acid test will be the ease with which individuals from different backgrounds are able to move within and across these roles.

${ }^{162}$ Francis and McDonald, op.cit. n140 and Brown and Hesketh op.cit. n43, p.219.

${ }^{163}$ M. Archer, Realist Social Theory: The Morphogenic Approach (1995) 247-93

${ }^{164}$ Tomlinson op.cit. n43, pp.85-6.

${ }^{165}$ H Sommerlad and P. Sanderson Gender, Choice and Commitment (1998)
} 